\title{
Preparation of some derivatives of (+)-usnic acid with aromatic amines under microwave irradiation condition
}

\section{- Nguyen Trung Giang}

Tan Tao University

\section{- Luu Hoang Duy Khuong}

- Nguyen Kim Phi Phung

University of Science, VNU-HCM

(Received on December $12^{\text {th }} 2014$, accepted on August $12^{\text {th }} 2015$ )

\section{ABSTRACT}

Up to now, derivatives of usnic acid were only prepared by classical methods of refluxing in organic solvents for hours. In this study, we examined the condensation reaction of usnic acid with o-toluidine under

Key words: (+)-Usnic acid, o-toluidine, microwave irradiation condition, condensation reaction, cyclopentyl methyl ether.

\section{INTRODUCTION}

Usnic acid (1), 2,6-diacetyl-7,9-dihydroxy8,12-dimethyl-1,3-(2H,12H)-dibenzofurandione, is a naturally occurring dibenzofurane derivative found in several lichen species. Usnic acid was identified in many genera of lichens including Alectoria, Cladonia, Evernia, Parmotrema, Ramalia, and Usnea, and it exists in one of two enantiomers which differ in the orientation of the methyl group located in position 12. It was first isolated by the German scientist W. Knop in 1844 [1].
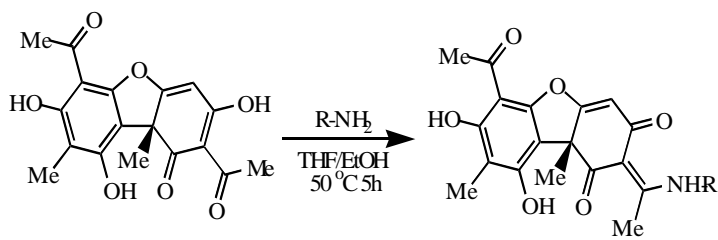

Fig 1. Condensation reaction of (+)-usnic acid with some amines.[3, 4] microwave irradiation condition which gave good yield in a short time. The obtained optimal condition was applied to prepare some other derivatives of (+)-usnic acid.

Usnic acid possesses a wide range of interesting biological properties. It is a potent antibiotic effective against Gram-positive bacteria, including Mycobacterium tuberculosis, Staphylococcus, Streptococcus and Pneumococcus. It also exhibits antiviral, antiprotozoal, antimitotic, anti-inflammatory and anticancer [2].

In 2006, Sophie Tomasi and co-workers [3] performed condensation reaction of usnic acid with some amines, diamines and triamines. In 2008 and 2009, similar processes were performed by some authors [4].

All reactions on usnic acid were done by refluxing for some hours in organic solvents such as tetrahydrofuran (THF), benzene,,.. which were commonly harmful. For that reasons, we 
examined these reactions under microwave irradiation condition with the aim obtaining new compounds by using the reaction conditions which were more friendly with the environment.

\section{EXPERIMENTAL}

\section{Materials}

THF (99 \%), ethanol (99.7\%), o-toluidine were purchased from Kanto-Japan, cyclopentyl methyl ether (CPME) was from Aldrich, and methanol for HPLC was purchased from Labscan. (+)-Usnic acid $(\underline{\mathbf{1}})\left([\alpha]_{\mathrm{D}}+451.4\right.$, c' $0.327 \mathrm{~g} / 100$ $\mathrm{mL}$ in $\left.\mathrm{EtOH}: \mathrm{CHCl}_{3} 4: 1\right)$ was isolated from lichen Parmotrema praesorediosum with the purety of $98.5 \%$ determined by HPLC. Amines were purchased from Aldrich.

\section{Equipments}

Discover oven (CEM). HPLC Agilent 1100 series, $\mathrm{C}_{18}$ column Agilent Zorbax $15 \mathrm{~mm}$ x 4.6 $\mathrm{mm} \times 3 \mu \mathrm{m}$, temperature $40{ }^{\circ} \mathrm{C}$, detector $\mathrm{UV}$, wavelength $282 \mathrm{~nm}$. The column was maintained at $40{ }^{\circ} \mathrm{C}$, mobile phase $\mathrm{A}$ was water, mobile phase $\mathrm{B}$ was methanol. The gradient parameters were 60 $\% \mathrm{~B}$ for 10 minutes, $80 \% \mathrm{~B}$ for $15-20$ minutes, and $100 \% \mathrm{~B}$ for $25-30$ minutes. NMR spectra were measured on a Bruker Avance III spectrometer, at $500 \mathrm{MHz}$ for ${ }^{1} \mathrm{H}$ NMR and 125 $\mathrm{MHz}$ for ${ }^{13} \mathrm{C}$ NMR, using residual solvent signal as internal reference: chloroform- $d \delta_{\mathrm{H}} 7.24, \delta_{\mathrm{C}}$ 77.23. The HR-ESI-MS were recorded on a HRESI-MS MicroOTOF-Q mass spectrometer.

\section{Experimental procedures}

Microwave irradiation method.

In a $10 \mathrm{~mL}$ test tube of a dedicated microwave oven, $\underline{\mathbf{1}}(\mathrm{x} \mathrm{mM}), o$-toluidine (y $\mathrm{mM})$, and solvent (ethanol, THF or CPME) were added. The solution attained naturally $\mathrm{pH} \mathrm{5,} \mathrm{the} \mathrm{optimal}$ $\mathrm{pH}$ condition for condensation reactions. Then the solution was irradiated at a power of $60 \mathrm{~W}$. The reaction conditions were changed such as: temperature, time, ratio of substrate and reactant and kind of solvents. After the reaction, the percentage $(\mathrm{H} \%)$ of the performed product $(\underline{\mathbf{3}})$ was determined by HPLC.

$$
H=\frac{H_{a} \times a}{0.05 \times M_{p}} \%
$$

Where:

a: The mass of the crude obtained product.

$\mathrm{M}_{\mathrm{p}}$ : The molecular weight of the product ( $\left.\underline{\mathbf{3}}\right)$.

$\mathrm{H}_{\mathrm{a}}$ : The percentage of the product $(\underline{\boldsymbol{3}})$ in HPLC spectrum.

0.05: The molar concentration $(\mathrm{mM})$ of the starting material $(\underline{\mathbf{1}})$ of the infected solution

After the reaction, the mixture was cooled and the light yellow precipitate was filtered off, washed with hot water, and dried for $24 \mathrm{hrs}$ in a dessicator. The results were presented in Table 1 .

The obtained optimal condition was applied to prepare some derivatives (Table 2 ) of (+)-usnic acid.

\section{Conventional heating refluxing method.}

A solution of $\underline{\mathbf{1}}(0.1 \mathrm{mM})$ and $o$-toluidine $(0.1$ $\mathrm{mM})$ in CPME (5 mL) was refluxed and stirred at 500 rounds/min. Twelve different experiments were prepared in order to determine the yield of the product, determined by HPLC, owing to time (1-12 hours).

\section{RESULTS}

Condensation reaction of (+)-usnic acid with $o$ toluidine

\section{Effect of the reaction temperature}

The yield increased when the temperature of the solution was raised from 80 to $90{ }^{\circ} \mathrm{C}$ (entries 1,2 of Table 1), but from $90{ }^{\circ} \mathrm{C}$ to $110{ }^{\circ} \mathrm{C}$, the yield 
began to decrease (entries 3,4$)$. This result was due to the formed side-product (4). Therefore, the good yield of reaction was achieved at $90{ }^{\circ} \mathrm{C}$. The result showed that the higher the temperature was, the lower reaction selectivity took place.<smiles>CC(=O)C1=C(O)C=C2Oc3c(C(C)=O)c(O)c(C)c(O)c3C(=O)[C@]2(C)C1=O</smiles>
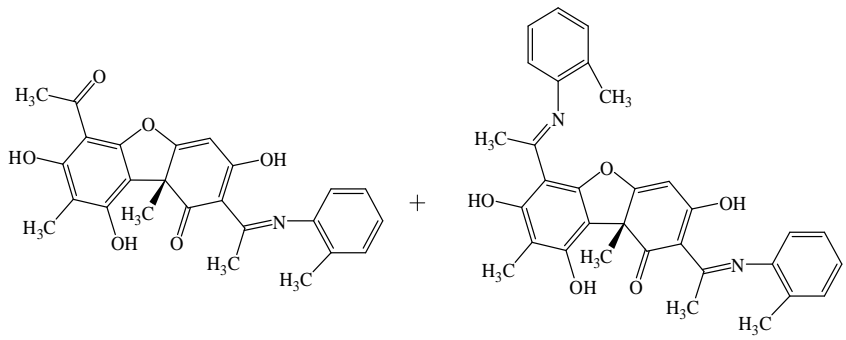

Fig 2. Condensation reaction of (+)-usnic acid with o-toluidine

Effect of the reaction time

In order to investigate the role of the reaction time, the reaction was carried out within 15-20 minutes at $\mathrm{pH} 5$ and other conditions were kept unchanged (entries 2, 5, 6 of Table 1). The good yield of reaction was achieved in 20 minutes (entry 2).

\section{Effect of the quantity of o-toluidine}

The reaction of $\underline{\mathbf{1}}$ and $o$-toluidine with the ratio of (1:1) gave highest yield of $93.9 \%$. When the ratio of $o$-toluidine was increased, the excess amine would react with both carbonyl groups, C14 and $\mathrm{C}-17$ of usnic acid, to create the side product $\underline{4}$.

\section{Effect of solvent}

Under microwave irradiation condition,
CPME, ethanol or TMF gave appropriate results and among them, CPME gave the best. CPME is a green solvent and is no harmful to the human health and the environment, therefore, it was chosen for the following experiments.

\section{Conventional heating refluxing method}

As time increased from 1 to 9 hours, the yield also increased from $11.2 \%$ (1 hour) to $58.2 \%$ (9 hours) and reached the highest $62.2 \%$ at 10 hours. More than 10 hours, the yield was not be ameliorated $(60.2 \%)$.

The results showed that the reaction yield performed under microwave irradiation condition was higher and quicker than under the conventional method, therefore this condition was applied to prepare some derivatives of (+)-usnic acid. 
Table 1. Condensation reaction (+)-usnic acid with o-toluidine under microwave irradiation condition.

\begin{tabular}{|c|c|c|c|c|c|c|c|c|c|c|}
\hline \multirow{2}{*}{ Entry } & \multirow{2}{*}{$\begin{array}{l}\text { Temp. } \\
\left({ }^{\circ} \mathrm{C}\right)\end{array}$} & \multirow{2}{*}{$\begin{array}{l}\text { Time } \\
\text { (min.) }\end{array}$} & \multirow{2}{*}{$\begin{array}{l}\underline{\mathbf{1}}: \underline{\mathbf{2}}^{\mathrm{a}} \\
(\mathrm{x}: \mathrm{y})\end{array}$} & \multirow{2}{*}{$\begin{array}{l}\text { Solvent } \\
(1 \mathrm{~mL})\end{array}$} & \multirow{2}{*}{$\mathrm{pH}$} & \multicolumn{4}{|c|}{ HPLC (\%) } & \multirow{2}{*}{$\begin{array}{r}\text { Yield }^{\prime} \\
(\%)\end{array}$} \\
\hline & & & & & & $\underline{1}$ & $\underline{2}$ & $\underline{\mathbf{3}}$ & $\underline{4}$ & \\
\hline 1 & 80 & 20 & $1: 2$ & Ethanol & 5 & - & 2.6 & 62.9 & 34.5 & 58.1 \\
\hline 2 & 90 & 20 & $1: 2$ & Ethanol & 5 & - & 3.6 & 86.0 & 10.4 & 83.4 \\
\hline 3 & 100 & 20 & $1: 2$ & Ethanol & 5 & - & 1.7 & 84.0 & 14.3 & 76.4 \\
\hline 4 & 110 & 20 & $1: 2$ & Ethanol & 5 & - & 1.5 & 76.6 & 21.9 & 74.7 \\
\hline 5 & 90 & 15 & $1: 2$ & Ethanol & 5 & - & 2.0 & 45.7 & 52.3 & 41.2 \\
\hline 6 & 90 & 25 & $1: 2$ & Ethanol & 5 & - & 2.5 & 66.1 & 31.4 & 64.6 \\
\hline 7 & 90 & 20 & $1: 1.5$ & Ethanol & 5 & - & 3.6 & 89.0 & 7.4 & 85.3 \\
\hline 8 & 90 & 20 & $1: 1$ & Ethanol & 5 & - & - & 96.0 & 4.0 & 92.7 \\
\hline 9 & 90 & 20 & $1: 1$ & THF & 5 & - & - & 95.0 & 5.0 & 91.0 \\
\hline 10 & 90 & 20 & $1: 1$ & CPME & 5 & - & - & 98.2 & 1.8 & 96.9 \\
\hline
\end{tabular}

Molar ratio

b The yield of $\underline{\mathbf{3}}$ was determined based on the percentage of HPLC

\section{Preparation of some derivatives of (+)-usnic acid}

The obtained optimal condition was applied to prepare some derivatives of (+)-usnic acid. The results were presented in Table 2.

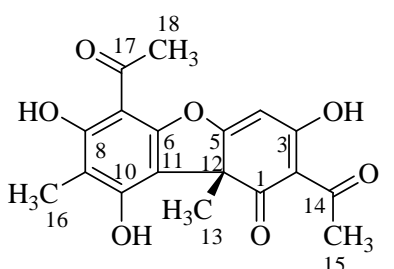

(+)-Usnic acid (17 mg; $0.05 \mathrm{mM})$

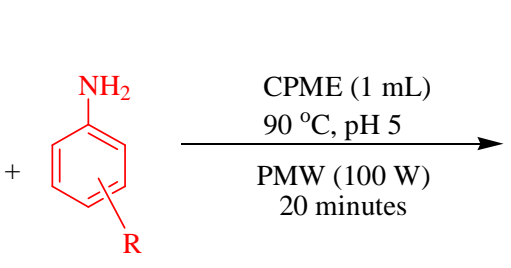

$0.05 \mathrm{mM}$

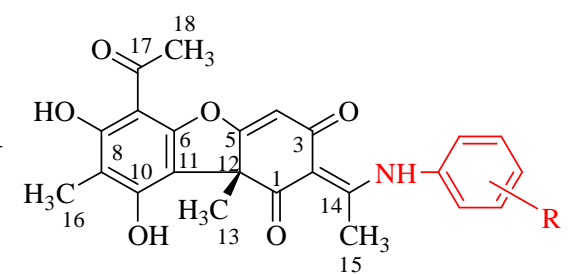

15

Fig 3. Process for preparing some derivatives of (+)-usnic acid

\section{DISCUSSIONS}

The condensation reaction of usnic acid and amine at the ratio of $(1: 1)$ gave the enaminoadduct performed at the carbonyl group C-14 of usnic acid. If the molar ratio was (1:2), the sideproduct was performed in which the two carbonyl groups at C-14 and C-17 were attacked. These results were compatible with published data in the literature $[3,4]$. The structures of all adducts were confirmed by 1D and 2D-NMR and HR-ESI-MS. Some HMBC experiments, of UA and UT, were presented in Fig. 4. All adducts from aromatic amines showed no correlations of the signal at $\delta_{\mathrm{H}}$ 14.93 (NH) to the neighboring carbons of usnic acid (C-2,14,15), but happily the HMBC experiment of UT, the adduct from an aliphatic amine, showed clear correlations of the signal at $\delta_{\mathrm{H}} 3.44(\mathrm{H}-19)$ to the neighboring carbon of usnic acid (C-14).

The chemical structure of adducts in the enamine form was well confirmed by the chemical shifts values of some carbons, as the followings:

\section{Trang 116}


C-3, as a phenolic carbon with $\delta_{\mathrm{C}} 191.88$ in usnic acid, was changed to a conjugated quinone with $\delta_{\mathrm{C}} 190-195$ in enamine-adducts.

C-14, as a ketone group with $\delta_{\mathrm{C}} 200.4$ in usnic acid, was changed to the enamine group with $\delta_{\mathrm{C}}$ $174-175$.

$\mathrm{C}-15$, as a methyl group adjacent to a ketone group with $\delta_{\mathrm{C}} 27.95$ in usnic acid, was changed to

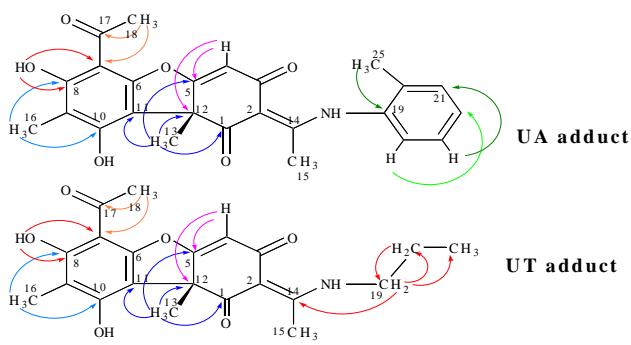

Fig 4. Keys of HMBC correlations of UA and UT a methyl adjacent to an alkene group with $\delta_{\mathrm{C}}$ 18.05-18.46.

Furthermore, the calculation of the active energy of two structures by DFT:B3LYP with the basis 6-31G(d,p) method in methanol, tetrahydrofuran and gas, the energy of the enamine form is lower than that of the imine one. These results showed that obtained adducts were in the enamine form.

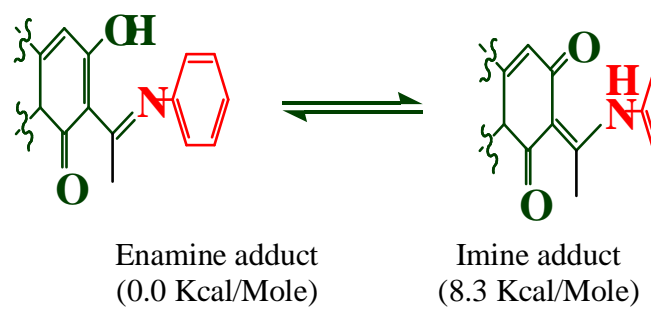

Fig 5. Active energy caculated by DFT:B3LYP method of two tautomers

Table 2. Results of condensation reaction (+)-usnic acid with 11 aromatic and 1 aliphatic amines.

\begin{tabular}{|c|c|c|c|}
\hline Entry & $\mathbf{A r}-\mathbf{N H}_{2}$ & $\begin{array}{c}\text { Code of } \\
\text { compound }\end{array}$ & $\begin{array}{l}\text { Yield } \\
(\%)\end{array}$ \\
\hline 1 & & UR & 64.8 \\
\hline 2 & & UA & 96.9 \\
\hline 3 & & UB & 96.7 \\
\hline 4 & & $\mathrm{UC}$ & 75.5 \\
\hline 5 & & UQ & 87.4 \\
\hline 6 & & UE & 94.7 \\
\hline 7 & & UF & 91.8 \\
\hline 8 & & UD & 89.7 \\
\hline 9 & & $\mathrm{UH}$ & 68.8 \\
\hline
\end{tabular}




\begin{tabular}{|l|c|c|c|}
\hline 10 & & $\mathrm{UK}$ & 67.6 \\
\hline 11 & \\
\hline
\end{tabular}

\section{Spectral data of obtained products}

- UA: HR-ESI-MS: $m / z 456.1418[\mathrm{M}+\mathrm{Na}]^{+} .{ }^{1} \mathrm{H}$ NMR $\left(\mathrm{CDCl}_{3}\right), \delta(\mathrm{ppm}): 1.80(s, 3 \mathrm{H}), 2.13(s, 3 \mathrm{H})$, $2.31(s, 3 \mathrm{H}), 2.53(s, 3 \mathrm{H}), 2.72(s, 3 \mathrm{H}), 5.91(s, 1 \mathrm{H}), 7.14(d, 1 \mathrm{H}, J=7.0 \mathrm{~Hz}), 7.33(m, 3 \mathrm{H}), 11.91(s, \mathrm{OH})$, $13.38(s, \mathrm{NH}), 14.93(s, \mathrm{OH}) .{ }^{13} \mathrm{C}$ NMR $\left(\mathrm{CDCl}_{3}\right), \delta(\mathrm{ppm}): 7.61$ (C-16), 18.05 (C-15), 20.03 (C-25), 31.41 (C-13), 32.15 (C-18), 57.53 (C-12), 92.81 (C-4), 101.53 (C-7), 102.49 (C-11), 105.09 (C-2), 108.30 (C9), 126.53 (C-21), 127.16 (C-23), 128.80 (C-20), 131.49 (C-22), 134.07 (C-24), 135.20 (C-19), 155.95 (C-6), 158.35 (C-10), 163.69 (C-8), 166.36 (C-14), 174.81 (C-5), 195.86 (C-3), 198.83 (C-1), 200.78 (C17).

- UB: HR-ESI-MS: $m / z 434.1614[\mathrm{M}+\mathrm{H}]^{+} .{ }^{1} \mathrm{H}$ NMR $\left(\mathrm{CDCl}_{3}\right), \delta(\mathrm{ppm}): 1.43(s, 3 \mathrm{H}), 1.75(s, 3 \mathrm{H})$, $2.10(s, 3 \mathrm{H}), 2.57(s, 3 \mathrm{H}), 2.69(s, 3 \mathrm{H}), 5.88(s, 1 \mathrm{H}), 7.14(d, 2 \mathrm{H}, J=8.5 \mathrm{~Hz}), 7.45(d, 2 \mathrm{H}, J=8.5 \mathrm{~Hz})$, $11.70(s, \mathrm{OH}), 13.34(s, \mathrm{NH}), 15.09(s, \mathrm{OH})$.

- UC: HR-ESI-MS: $m / z 436.1419[\mathrm{M}+\mathrm{H}]^{+} .{ }^{1} \mathrm{H}$ NMR $\left(\mathrm{CDCl}_{3}\right), \delta(\mathrm{ppm}): 1.76(s, 3 \mathrm{H}), 2.11(s, 3 \mathrm{H})$, $2.57(s, 3 \mathrm{H}), 2.69(s, 3 \mathrm{H}), 2.70(s, 3 \mathrm{H}), 5.88(s, 1 \mathrm{H}), 6.92(d, 2 \mathrm{H}, J=8.5 \mathrm{~Hz}), 7.06(d, 2 \mathrm{H}, J=8.5 \mathrm{~Hz})$, $11.89(s, \mathrm{OH}), 13.36(s, \mathbf{O H}), 14.83(s, \mathbf{N H})$.

- UD: HR-ESI-MS: $m / z 498.07[\mathrm{M}+\mathrm{H}]^{+} .{ }^{1} \mathrm{H}$ NMR (CDCl3), $\delta(\mathrm{ppm}): 1.76(s, 3 \mathrm{H}), 2.11(s, 3 \mathrm{H}), 2.57$ $(s, 3 \mathrm{H}), 2.69(s, 3 \mathrm{H}), 5.88(s, 1 \mathrm{H}), 7.08(d, 2 \mathrm{H}, J=8.5 \mathrm{~Hz}), 7.61(d, 2 \mathrm{H}, J=8.5 \mathrm{~Hz}), 11.70(s, \mathrm{OH}), 13.35$ $(s, \mathrm{OH}), 15.09(s, \mathrm{NH})$.

- UE: HR-ESI-MS: $m / z 450.1566[\mathrm{M}+\mathrm{H}]^{+} .{ }^{1} \mathrm{H}$ NMR $\left(\mathrm{CDCl}_{3}\right), \delta(\mathrm{ppm}): 1.76(s, 3 \mathrm{H}), 2.11(s, 3 \mathrm{H})$, $2.56(s, 3 \mathrm{H}), 2.69(s, 3 \mathrm{H}), 3.85(s, 3 \mathrm{H}), 5.87(s, 1 \mathrm{H}), 6.97(d, 2 \mathrm{H}, J=8.5 \mathrm{~Hz}), 7.11(d, 2 \mathrm{H}, J=8.5 \mathrm{~Hz})$, $11.88(s, \mathrm{OH}), 13.35(s, \mathrm{NH}), 14.87(s, \mathrm{OH})$.

- UF: HR-ESI-MS: $m / z 450.1569[\mathrm{M}+\mathrm{H}]^{+} .{ }^{1} \mathrm{H}$ NMR $\left(\mathrm{CDCl}_{3}\right), \delta(\mathrm{ppm}): 1.77(s, 3 \mathrm{H}), 2.11(s, 3 \mathrm{H})$, $2.54(s, 3 \mathrm{H}), 2.69(s, 3 \mathrm{H}), 3.88(s, 3 \mathrm{H}), 5.87(s, 1 \mathrm{H}), 7.03(t, 2 \mathrm{H}, J=7.5 \mathrm{~Hz}), 7.15(d, 1 \mathrm{H}, J=7.5 \mathrm{~Hz})$, $7.36(t, 1 \mathrm{H}, J=7.5 \mathrm{~Hz}), 11.96(s, \mathrm{OH}), 13.36(s, \mathrm{OH}), 14.78(s, \mathrm{NH})$

- UH: HR-ESI-MS: $m / z 454.1059[\mathrm{M}+\mathrm{H}]^{+} .{ }^{1} \mathrm{H}$ NMR $\left(\mathrm{CDCl}_{3}\right), \delta(\mathrm{ppm}): 1.76(s, 3 \mathrm{H}), 2.11(s, 3 \mathrm{H})$, $2.57(s, 3 \mathrm{H}), 2.69(s, 3 \mathrm{H}), 5.88(s, 1 \mathrm{H}), 7.14(d, 2 \mathrm{H}, J=8.5 \mathrm{~Hz}), 7.45(d, 2 \mathrm{H}, J=8.5 \mathrm{~Hz}), 11.71(s, \mathrm{OH})$, $13.35(s, \mathrm{OH}), 15.09(s, \mathrm{NH})$

- UI: HR-ESI-MS: $m / z 470.1610[\mathrm{M}+\mathrm{H}]]^{+} .{ }^{1} \mathrm{H}$ NMR $\left(\mathrm{CDCl}_{3}\right), \delta(\mathrm{ppm}): 1.85(s, 3 \mathrm{H}), 2.14(s, 3 \mathrm{H})$, $2.55(s, 3 \mathrm{H}), 2.74(s, 3 \mathrm{H}), 5.98(s, 1 \mathrm{H}), 7.38(d, 1 \mathrm{H}, J=7.0 \mathrm{~Hz}), 7.58(t, 1 \mathrm{H}, J=7.5 \mathrm{~Hz}), 7.63(m, 2 \mathrm{H})$, $7.86(m, 1 \mathrm{H}), 7.98(m, 2 \mathrm{H}), 11.88(s, \mathrm{OH}), 13.40(s, \mathrm{NH}), 15.34(s, \mathrm{OH})$.

\section{Trang 118}


- UK: HR-ESI-MS: $m / z 464.1703[\mathrm{M}+\mathrm{H}]^{+} .{ }^{1} \mathrm{H}$ NMR $\left(\mathrm{CDCl}_{3}\right), \delta(\mathrm{ppm}): 1.77(s, 3 \mathrm{H}), 2.11(s, 3 \mathrm{H})$, $2.59(s, 3 \mathrm{H}), 2.69(s, 3 \mathrm{H}), 2.93(t, 2 \mathrm{H}, J=5.0 \mathrm{~Hz}), 3.92(t, 2 \mathrm{H}, J=5.0 \mathrm{~Hz}), 5.88(s, 1 \mathrm{H}), 7.14(d, 2 \mathrm{H}, J=$ $8.5 \mathrm{~Hz}), 7.35(d, 2 \mathrm{H}, J=8.0 \mathrm{~Hz}), 11.83(s, \mathrm{OH}), 13.35(s, \mathrm{NH}), 15.02(s, \mathrm{OH})$.

- UQ: HR-ESI-MS: $m / z 436.14[\mathrm{M}+\mathrm{H}]^{+} .{ }^{1} \mathrm{H}$ NMR $\left(\mathrm{CDCl}_{3}\right), \delta(\mathrm{ppm}): 1.68(s, 3 \mathrm{H}), 2.03(s, 3 \mathrm{H}), 2.56$ $(s, 3 \mathrm{H}), 2.66(s, 3 \mathrm{H}), 5.76(s, 1 \mathrm{H}), 7.01(t, 1 \mathrm{H}, J=7.5 \mathrm{~Hz}), 7.06(d, 1 \mathrm{H}, J=8.0 \mathrm{~Hz}), 7.11(d, 1 \mathrm{H}, J=8.0$ $\mathrm{Hz}), 7.31(t, 1 \mathrm{H}, J=7.5 \mathrm{~Hz}), 11.43(s, \mathrm{OH}), 13.31(s, \mathrm{OH}), 14.36(s, \mathrm{NH})$.

- UR: HR-ESI-MS: $m / z 420.1417[\mathrm{M}+\mathrm{H}]^{+} .{ }^{1} \mathrm{H}$ NMR $\left(\mathrm{CDCl}_{3}\right), \delta(\mathrm{ppm}): 1.76(s, 3 \mathrm{H}), 2.11(s, 3 \mathrm{H})$, $2.58(s, 3 \mathrm{H}), 2.69(s, 3 \mathrm{H}), 5.88(s, 1 \mathrm{H}), 7.20(d, 2 \mathrm{H}, J=7.5 \mathrm{~Hz}), 7.40(t, 1 \mathrm{H}, J=7.5 \mathrm{~Hz}), 7.48(t, 2 \mathrm{H}, J=$ $7.5 \mathrm{~Hz}), 11.83(s, \mathrm{OH}), 13.36(s, \mathrm{OH}), 15.06(s, \mathrm{NH})$.

- UT: HR-ESI-MS: $m / z 386.10[\mathrm{M}+\mathrm{H}]^{+} .{ }^{1} \mathrm{H}$ NMR $\left(\mathrm{CDCl}_{3}\right), \delta(\mathrm{ppm}): 1.07(t, 3 \mathrm{H}, J=7.5 \mathrm{~Hz}), 1.69$ $(s, 3 \mathrm{H}), 1.77(m, 2 \mathrm{H}), 2.07(s, 3 \mathrm{H}), 2.62(s, 3 \mathrm{H}), 2.65(s, 3 \mathrm{H}), 3.44(m, 2 \mathrm{H}), 5.76(s, 1 \mathrm{H}), 11.96(s, 10-$ $\mathrm{OH}), 13.33(s, 8-\mathrm{OH}) .{ }^{13} \mathrm{C}$ NMR $\left(\mathrm{CDCl}_{3}\right), \delta(\mathrm{ppm}): 7.58(\mathrm{C}-16), 11.52(\mathrm{C}-21), 18.46(\mathrm{C}-15), 22.44(\mathrm{C}-$ 20), 31.37 (C-13), 32.14 (C-18), 45.81 (C-19), 57.13 (C-12), 101.46 (C-7), 102.29 (C-2), 102.60 (C-4), 105.23 (C-11), 108.04 (C-9), 156.02 (C-6), 158.42 (C-10), 163.58 (C-8), 174.16 (C-5), 175.00 (C-14), 190.25 (C-3), 198.31 (C-1), 200.79 (C-17).

\section{CONCLUSION}

Condensation reaction of usnic acid with $o$ solvent for the reaction with the yield of $96.9 \%$. toluidine under microwave irradiation condition gave better yield in a short time comparing to the conventional heating method. The best condition of condensation reaction between (+)-usnic acid and $o$-toluidine $(1: 1)$ was irradiated at $90^{\circ} \mathrm{C}$ within 20 minutes. Cyclopentyl methyl ether is a good Some new derivatives of (+)-usnic acid were prepared and this is the first time their

NMR spectral data are reported.

Acknowledgements: This research was supported by Vietnam's National Foundation for Science and Technology Development (NAFOSTED) grant \# 104.01-2013.17.

\section{Điều chế một số dẫn xuất của acid (+)-usnic với amine thơm trong điều kiện chiếu xạ vi sóng}

- Nguyễn Trung Giang

- Trường Đại học Tân Tạo

- Lưu Hoàng Duy Khương

- Nguyễn Kim Phi Phụng

Trường Đại học Khoa học Tự nhiên, ĐHQG-HCM

\section{TÓM TÁT}

Cho đến nay, dù acid usnic và một số dẫn xuất của nó được biết có những hoạt tính

sinh học hấp dẫn, tuy nhiên, số lượng công trình nghiên cứu về các điều chế dẫn xuất của 
acid usnic còn nhiều hạn chế và hầu như các phản ứng đều được thực hiện bằng cách đun nóng trong dung môi hữu cơ theo phương pháp cổ điển. Trong bài báo này, chúng tôi khảo sát phản ứng ngưng tu giữa acid (+)usnic với o-toluidine trong điều kiện chiếu xạ vi sóng, sau đó, áp dụng điều kiện tối ưu để điều chế một số dẫn xuất mới của acid usnic. Đây là lần đầu tiên các dẫn xuất này được điều chế và được trình bày về số liệu phổ NMR. Phần thực nghiệm có thực hiện lại phản ưng ngưng tụ trong điều kiện theo phương pháp cổ điển để có số liệu so sánh giữa hai phương pháp.

Từ khoá: Acid (+)-usnic, o-toluidine, điều kiện chiếu xạ vi sóng, phản ứng ngưng tụ, cyclopentyl methyl ether.

\section{REFERENCES}

[1]. W. Knop, Chemisch - physiologische Untersuchung uber die Flechten, Justus Lieb. Ann. Chern, 49, 103-124 (1844).

[2]. M. Cocchietto, N. Skert, A review on usnic acid, an interesting natural compound, Naturwissenschaften, 89, 137- 146 (2002).

[3]. S. Tomasi, S. Picard, Solid - phase synthesis of polyfunctionalized natural

products: Aplication to usnic acid, a bioactive lichen compound, J. Com. Chem., 11-14 (2006).

[4]. B. Antoine-Marc, A. Cecile, Synthesis and cytotoxic activities of usnic acid derivatives, Bioorganic \& Medicinal Chemistry, 16, 6860-6866 (2008). 